\title{
EVALUASI SISTEM KERJA DI INDUSTRI KERAJINAN BATIK KAYU SANGGAR ARJUNA DESA KREBET PAJANGAN BANTUL DENGAN PENDEKATAN MACROERGONOMIC ANALYSIS AND DESIGN
}

\author{
Dyah Rachmawati L dan Tri Wibawa \\ Jurusan Teknik Industri FTI Universitas Pembangunan Nasional "Veteran" Yogyakarta \\ Jl. Babarsari 2 Tambakbayan, Yogyakarta, 55281 \\ Telp. (0274) 485363 Fax: (0274) 486256
}

\begin{abstract}
Abstrak
Industri Batik Kayu Sanggar Arjuna Desa Krebet, Pajangan, Bantul bergerak di bidang industri kerajinan khususnya batik dengan bahan untuk dasaran dari kayu yang memproduksi berbagai produk. Produk kerajinan yang dihasilkan adalah seperti topeng, wayang, nampan, asesoris rumah tangga, patung kayu, kotak perhiasan, dan hiasan batik kayu lainnya. Keadaan sistem kerja yang ada masih belum optimal yang meliputi faktor lingkungan fisik, peralatan mesin, kondisi pekerjaan, dan organisasi. Hal tersebut berdasarkan dari keluhan pekerja bagian produksi, dimana hal itu mempengaruhi waktu menyelesaikan produksi.

Penelitian ini mengevaluasi sistem kerja yang ada dari keempat faktor yang telah dijelaskan dengan pendekatan Macroergonomic Analysis and Design (MEAD). Tujuan dari penelitian ini adalah untuk mengidentifikasi faktor kunci yang terjadi pada sistem kerja dan membuat usulan perbaikan berdasarkan faktor kunci terpilih. Macroergonomic Analysis and Design (MEAD) dapat membantu menganalisis sumber masalah paling signifikan pada sistem kerja sehingga dapat dibuat usulan perbaikan sistem kerja yang bisa dilakukan.

Berdasarkan hasil pengolahan data, faktor kunci yang terpilih yaitu lingkungan fisik dengan varian yang meliputi suhu dan kebisingan. Usulan perbaikan yang bisa dilakukan terdiri dari 2 alternatif. Alternatif pertama yaitu pengadaan fasilitas lingkungan fisik yang meliputi pengadaan kipas angin pada masing-masing ruang, ruang I menggunakan exhaust fan yang memiliki volume udara 1183,22 CFM sebanyak 9 buah dan ruang II menggunakan exhaust fan yang memiliki volume udara 321,41 CFM sebanyak 3 buah, sedangkan ruang III menggunakan ceiling fan dengan volume udara 223,69 CFM sebanyak 3 buah. Pengadaan fasilitas selanjutnya yaitu pengadaan formable earplug sebanyak 38 sesuai jumlah pekerja produksi, sosialisasi penggunaan earplug yang baik dan benar, sertapemasangan display informasi peringatan dan petunjuk penggunaan earplug. Sedangkan alternatifkedua yaitu perbaikan kebijakan pengaturan kerja dengan penambahan waktu istirahat sebesar 10,24 menit.
\end{abstract}

Keywords: Macroergonomic Analysis and Design (MEAD), lingkungan fisik, suhu,kebisingan, pencahayaan

\section{PENDAhUluAN}

Sistem kerja merupakan rangkaian tata kerja dan prosedur kerja yang kemudian membentuk suatu kebulatan pola tertentu dalam rangka melaksanakan suatu bidang pekerjaan (KBBI, 2005). Menurut Kleiner (2006), sistem kerja terdiri dari dua atau lebih orang yang bekerja bersama-sama (personel sub-sistem), berinteraksi dengan teknologi (technological sub-system) dalam sistem organisasi yang dicirikan oleh lingkungan internal (both physical and cultural). Menurut Freivald (2010) elemen-elemen sistem kerja terdiri dari organisasi, human, tasks, environment, dan tools/teknologi.
Menurut Kleiner (2006), sistem kerja terdiri dari dua atau lebih orang yang bekerja bersama-sama (personel sub-sistem), berinteraksi dengan teknologi (technological sub-system) dalam sistem organisasi yang dicirikan oleh lingkungan internal (both physical and cultural). Sistem kerja yang ada pada suatu perusahaan akan mempengaruhi jalannya produksi, oleh karenanya pengaturan sistem kerja yang baik sangat diperlukan bagi setiap perusahaan sebagai faktor penting dalam meningkatkan produktivitas kerja.

Industri Batik Kayu Sanggar Arjuna berada di Desa Krebet, Pajangan, Bantul bergerak di bidang industri kerajinan khususnya batik dengan bahan dasaran dari kayu. Industri ini memproduksi berbagai 
produk kerajinan yang dihasilkan seperti topeng, wayang, nampan, asesoris rumah tangga, patung kayu, kotak perhiasan, dan hiasan batik kayu lainnya. Kualitas produk yang bagus dan kecepatan waktu penyelesaian menjadi prioritas utama dalam menjaga kepuasan konsumen. Keadaan sistem kerja yang ada di Sanggar Arjuna belum optimal sehingga menyebabkan ketidaktepatan target waktu produksi atau produktivitas yang sering menurun. Sistem kerja yang belum optimal disebabkan oleh 4 faktor. Faktor pertama yaitu lingkungan fisik dimana suhu yang melebihi standar kondisi optimal $24^{\circ} \mathrm{C}$ (Wignjosoebroto, 1995) pada ruang I $35,2^{\circ} \mathrm{C}$, ruang II $36,3^{\circ} \mathrm{C}$, dan ruang III $33,1^{\circ} \mathrm{C}$, kemudian kebisingan pada masing-masing ruang yaitu $90 \mathrm{~dB}, 86 \mathrm{~dB}$, dan $93 \mathrm{~dB}$ dimana ambang batas kebisingan yang diizinkan 85 dB (Tarwaka et.al, 2004). Faktor kedua peralatan dan mesin yang berdasarkan hasil kuesioner sebanyak $68,42 \%$ pekerja mengatakan mesin mempengaruhi ketepatan waktu penyelesaian dan $65,79 \%$ mengatakan kerja yang lambat disebabkan masih menggunakan cara manual. Faktor ketiga kondisi pekerjaan yang berdasarkan hasil prosentase kuesioner $86,84 \%$ pekerja mengatakan mudah mengalami kelelahan dan target produksi sulit dipenuhi, 81,58 mengatakan mengalami stress kerja, serta 73,68\% mengatakan Alat Pelindung Diri (APD) yang belum memenuhi. Faktor keempat organisasi dimana 73,68\% pekerja mengatakan pimpinan kurang memperdulikan tempat kerja, $63,16 \%$ mengatakan pimpinan kurang peduli keadaan pekerja, 52,63\% mengatakan upah belum sesuai, $86,84 \%$ mengatakan penghargaan kurang diberikan, dan 57,89\% mengatakan kesejahteraan belum sesuai.

Penelitian ini bertujuan untuk mengevaluasi sistem kerja yang ada dari keempat faktor yang telah dijelaskan dengan pendekatan Macroergonomic Analysis and Design (MEAD). Berdeasarkan hasil evaluasi untuk mengidentifikasi faktor kunci yang terjadi pada sistem kerja dan membuat usulan perbaikan berdasarkan faktor kunci terpilih. Macroergonomic Analysis and Design (MEAD) dapat membantu menganalisis sumber masalah paling signifikan pada sistem kerja sehingga dapat dibuat usulan perbaikan sistem kerja yang bisa dilakukan.

\section{METODE PENELITIAN}

Dalam mengatasi kondisi sistem kerja yang belum optimal digunakan Macroergonomic Analysis and Design (MEAD) untuk mengevaluasi sistem kerja pada Industri Batik Kayu Sanggar Arjuna sehingga dapat diketahui faktor kunci dalam sistem kerja yang paling berpengaruh terhadap produktivitas dan dapat dibuat usulan perbaikan berdasarkan faktor kunci yang terpilih sehingga dapat memperbaiki sistem kerja menjadi lebih baik. Macroergonomic Analysis and Design (MEAD) merupakan metodologi yang menggambarkan tahapan implementasi ergonomi makro yang dapat digunakan untuk mengevaluasi dan merancang sistem kerja. Kerangka umum Macroergonomic Analysis and Design (MEAD) dikembangkan oleh Emery and Trist (1978) dalam Hendrick and Kleiner (2001).

\section{HASIL DAN PEMBAHASAN}

Dari hasil identifikasi faktor kunci diperoleh hasil bahwa subsistem lingkungan dan subsistem organisasi pada Industri Batik Kayu Desa Krebet, Pajangan, Bantul. Kondisi lingkungan fisik kerja yang dikeluhkan meliputi suhu, kebisingan, dan cahaya. Sedangkan kondisi organisasi yang dikeluhkan pekerja meliputi kesejahteraan, pembagian kerja, dan perhatian pimpinan terhadap keadaan pekerja dan lingkungan fisik kerja. Untuk mencapai ekspektasi performansi yang diinginkan, tidak terlepas dari peralatan dan mesin yang digunakan. Kondisi peralatan dan mesin masih terdapat kekurangan berdasarkan keluhan dari pekerja yaitu mengenai perawatan dan tenaga pembimbing ahli.

Unit operasi dibagi menjadi 3 ruang, ruang I untuk pembentukan bahan baku kayu menjadi kerajinan, ruang II untuk proses pembatikan, dan ruang III untuk perakitan asesoris kerajinan. Dalam pelaksanaan proses produksi, terdapat berbagai keluhan dari pekerja bagian produksi pada kondisi pekerjaan yang dilakukan. Keluhan tersebut antara lain mudah lelah, konsentrasi menurun, stress kerja, target produksi sulit dipenuhi, dan belum adanya alat peredam kebisingan.

Identifikasi data varian bertujuan untuk mengetahui permasalahan yang ada sehingga dapat memudahkan proses analisis selanjutnya. Faktor-faktor yang menimbulkan varian (lingkungan fisik, peralatan/mesin, 
kondisi pekerjaan, dan organisasi) dan varian yang terjadi sudah diidentifikasi pada langkah sebelumnya. Untuk memperoleh data varian yang lebih rinci dilakukan penyebaran kuesioner pada seluruh pekerja bagian produksi sehingga dapat diketahui permasalahan yang dihadapi seluruh pekerja bagian produksi. Setelah dilakukan perhitungan prosentase dari jawaban seluruh responden, dapat diidentifikasi data varian terpilih adalah fasilitas lingkungan fisik dan pengaturan jam kerja. Matriks varian bertujuan untuk mengetahui hubungan atau keterkaitan antar varian atau apakah varian yang satu mempengaruhi varian lainnya. Faktor yang variannya memiliki keterkaitan atau hubungan paling banyak dengan varian lain akan menjadi faktor kunci. Faktor kunci terpilih adalah factor lingkungan kerja dengan varian suhu, pencahayaan, dan kebisingan ruang kerja.

Suhu ruang kerja yang panas dan kebisingan yang terjadi sesuai dengan hasil pengukuran bahwa suhu pada ketiga ruangan kerja masing-masing $35,2^{\circ} \mathrm{C}, \quad 36,3^{\circ} \mathrm{C}$, dan $33,1^{\circ} \mathrm{C}$, sedangkan kebisingan yang terjadi pada ketiga ruangan tersebut melebihi $85 \mathrm{~dB}$ yaitu $90 \mathrm{~dB}, 86 \mathrm{~dB}$, dan $93 \mathrm{~dB}$. Pada kondisi pencahayaan di lingkungan kerja, sebagian besar pekerja tidak mengeluhkan mengenai pencahayaan seperti berdasarkan hasil prosentase yang menyatakan bahwa pencahayaan cukup. Hal tersebut juga sesuai dengan pengukuran yang dilakukan, ruang I pencahayaan sebesar 386 lux, ruang II 443 lux, dan ruang III 887 lux. Sesuai dengan Keputusan Menteri Kesehatan No. 1405 tahun 2002 bahwa untuk pekerjaan kasar dan terusmenerus (pekerjaan dengan mesin dan perakitan kasar) membutuhkan cahaya minimal yaitu 200 lux.

Penyusunan function allocation and joint design. Tahap ini bertujuan untuk membuat fungsi alokasi dan rancangan alternatif perbaikan dari tabel kendali varian dan varian kunci yang ada dalam bentuk objectives/activity tree. Rancangan alternatif yang ada dapat dilihat pada Gambar 1. Selanjutnya dilakukan evaluasi peran dan persepsi tanggungjawab. Pada tahap ini bertujuan untuk memberikan pembobotan untuk masing-masing alternatif perbaikan sehingga dapat diperoleh alternatif yang baik dan dapat diterapkan. Penilaian pembobotan dilakukan secara subyektif kriteria yang memiliki keterkaitan dengan alternatif.

Perancangan ulang subsistem pendukung bertujuan untuk membuat rancangan perbaikan pada subsistem yang dapat memperbaiki sistem kerja menjadi lebih baik sehingga produktivitas dapat ditingkatkan. Faktor kunci yang terpilih yaitu lingkungan fisik dengan varian meliputi suhu, pencahayaan dan kebisingan ruang kerja.

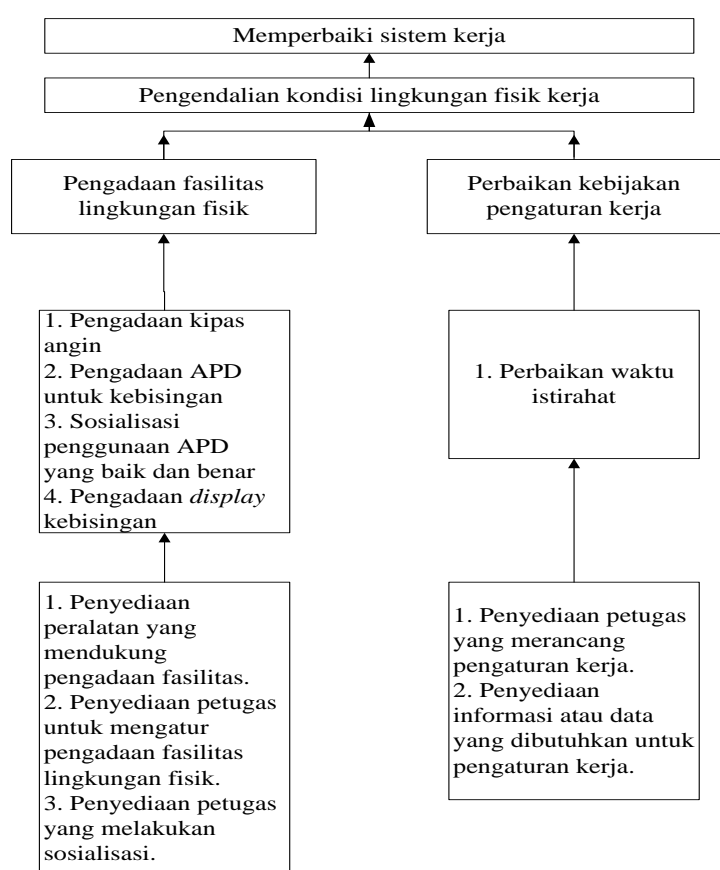

\section{Gambar 1. Objectives/activity tree}

Perancangan ulang subsistem pendukung bertujuan untuk membuat rancangan perbaikan pada subsistem yang dapat memperbaiki sistem kerja menjadi lebih baik sehingga produktivitas dapat ditingkatkan. Perancangan ulang dilakukan pada permasalahan yang merupakan faktor kunci. Faktor kunci yang terpilih yaitu lingkungan fisik dengan varian meliputi suhu ruang kerja yang panas dan kebisingan yang terjadi.

Pengadaan fasilitas lingkungan fisik berupa pengadaan kipas angin dapat dilakukan dengan menentukan jumlah kipas angin yang diperlukan pada ketiga ruang kerja tersebut. Untuk menentukan jumlah kipas yang dibutuhkan pada masing-masing ruang produksi, pertama ditentukan kapasitas kipas yang dibutuhkan (CFM) dalam ruangan. Ruang I membutuhkan kapasitas kipas sebesar 10586,27 CFM, ruang II membutuhkan kapasitas kipas sebesar 658,70 CFM, dan 
ruang III membutuhkan kapasitas kipas sebesar 564,60 CFM. Pemilihan kipas yang cocok untuk ruang I dan II adalah exhaust fan, tipe exhaust fan yang dapat digunakan sesuai dengan CFM kipas yang dibutuhkan pada ruang I yang memiliki volume udara 1183,22 CFM, sehingga jumlah exhaust fan yang dibutuhkan untuk ruang I sebanyak 9 buah. Tipe exhaust fan yang bisa digunakan sesuai dengan CFM kipas yang dibutuhkan pada ruang II yang memiliki volume udara 321,41 CFM, sehingga jumlah exhaust fan yang dibutuhkan untuk ruang II adalah 3 buah. Sedangkan untuk ruang III lebih cocok menggunakan ceiling fan karena ruangan yang terbuka sehingga sirkulasi udaranya lebih besar maka lebih baik menggunakan ceiling fan volume udara 223,69 CFM, sehingga jumlah ceiling fan yang dibutuhkan sebanyak 3 buah.

Pengadaan APD untuk kebisingan yang berupa earplug atau sumbat telinga dengan jumlah sesuai dengan jumlah pekerja sehingga jumlah earplug yang dibutuhkan adalah 38 buah. Earplug yang digunakan dapat berupa formable earplug dengan NRR $27 \mathrm{~dB}$. Dengan NRR $27 \mathrm{~dB}$ maka aktual NRR atau kebisingan yang dapat direduksi sebesar 10 dB. Sehingga, kebisingan yang terjadi pada masing-masing ruang berkurang menjadi 80 $\mathrm{dB}, 76 \mathrm{~dB}$, dan $83 \mathrm{~dB}$. Serta dosis kebisingan sesudah menggunakan earplug menjadi ruang I dan II $32 \%$, ruang III $66,67 \%$ dimana dosis kebisingan sebelum menggunakan earplug pada masing-masing ruang $400 \%, 133 \%$, $800 \%$.

Sosialisasi penggunaan APD yang baik dan benar. Setelah pemberian earplug dilakukan, perusahaan perlu menanamkan pemahaman kepada pekerja akan pentingnya penggunaan earplug dengan melakukan sosialisasi mengenai cara pemakaian APD yang baik dan benar, serta pentingnya penggunaan APD untuk meningkatkan kedisiplinan pekerja. Sosialisasi dapat dilakukan pada saat brefing sebelum mulai bekerja.

Pengadaan display kebisingan yang bertujuan agar pekerja mendapatkan informasi mengenai kebisingan yang terjadi. Pengadaan display meliputi display peringatan dan display petunjuk penggunaan earplug.

Perbaikan kebijakan pengaturan kerja dengan penambahan waktu istirahat. Beban kerja yang dialami pekerja bagian produksi sebesar $37,02 \%$ yang termasuk kategori beban kerja sedang dan diperlukan perbaikan. Konsumsi energi yang dikeluarkan sebesar $2,92 \mathrm{kkal} / \mathrm{menit}$. Sehingga waktu istirahat yang dibutuhkan sebesar 10 menit.

Faktor kunci yang diperoleh yaitu lingkungan fisik dengan varian suhu dan kebisingan. Alternatif yang bisa dilakukan adalah pengadaan fasilitas lingkungan fisik meliputi pengadaan kipas angin pada ruang I ruang I menggunakan exhaust fan yang memiliki volume udara 1183,22 CFM sebanyak 9 buah, ruang II yang memiliki volume udara 321,41 CFM sebanyak 3 buah, ruang III menggunakan kipas baling/ceiling fan dengan volume udara 223,69 CFM sebanyak 3 buah, pengadaan formable earplug sebanyak 38 buah sesuai jumlah pekerja, sosialisasi penggunaan APD yang baik dan benar yang dapat dilakukan pada saat brefing sebelum mulai kerja, dan pengadaan display peringatan kebisingan dan display petunjuk penggunaan earplug. Alternatif kedua yaitu perbaikan kebijakan pengaturan kerja yang berupa penambahan jam istirahat selama 10 menit. Dengan penambahan waktu istirahat dapat mengurangi konsumsi energi sebesar 2,58 kkal/menit sehingga kelelahan dapat berkurang.

Dengan diterapkannya penggunaan earplug dan penambahan waktu istirahat dapat mempercepat waktu penyelesaian 69 menit. Hal ini berarti menunjukkan bahwa waktu penyelesaian setelah penambahan earplug dan waktu istirahat mengalami percepatan yang cukup signifikan yaitu sebesar $16,7 \%$. Waktu istirahat yang diberikan mempengaruhi konsumsi energi yang dikeluarkan oleh pekerja. Semakin besar konsumsi energi yang dikeluarkan pekerja maka semakin besar juga kelelahan yang akan dialami saat bekerja. Rata-rata konsumsi energi sebelum penambahan jam istirahat sebesar 5,5 $\mathrm{kkal} /$ menit dan setelah penambahan jam istirahat 2,92 kkal/menit. Terdapat selisih konsumsi energi sebesar 2,58. Hal ini berarti setelah penambahan jam istirahat tingkat kelelahan pekerja menurun sebesar $46,9 \%$. Dengan penambahan jam istirahat dapat menurunkan konsumsi energi sehingga dapat mengurangi kelelahan yang dialami pekerja. Dengan berkurangnya kelelahan yang dialami maka pekerja bisa lebih fokus dan 
berkonsentrasi saat pekerja sehingga pekerjaan akan lebih cepat selesai. Dengan produktivitas yang dilihat dari waktu proses penyelesaian yang didapatkan percepatan sebesar 16,7\%, maka dapat dikatakan produktivitas pekerja meningkat dan sistem kerja menjadi lebih baik sesuai dengan standar kriteria sistem kerja yang baik menurut Sutalaksana et.al (1997) bahwa salah satu kriteria yang dipandang sebagai pengukur yang baik tentang sistem kerja adalah waktu penyelesaian yang singkat.

\section{KESIMPULAN}

Dari hasil analisis hasil pengumpulan data dapat ditarik simpulan sebagai berikut:

1. Strategi pengembangan sistem kerja didasarkan pada varian lingkungan fisik, peralatan dan mesin, kondisi pekerjaan, dan organisasi.

2. Faktor kunci yang mempengaruhi sistem kerja untuk meningkatkan produktivitas adalah lingkungan fisik yang terdiri dari varian suhu ruang, pencahayaan, dan kebisingan.

3. Perbaikan sistem kerja dilakukan dengan pengadaan fasilitas lingkungan fisik yang meliputi pengadaan kipas angin, pengadaan formable earplug sebanyak, sosialisasi penggunaan APD yang baik dan benar yang dapat dilakukan pada saat brefing sebelum mulai kerja, dan pengadaan display peringatan kebisingan dan display petunjuk penggunaan earplug.

4. Alternatif perbaikan kebijakan pengaturan kerja dengan cara penambahan jam istirahat selama 10 menit.

\section{DAFTAR PUSTAKA}

Adiatmika, I.P.G, 2006, Modifikasi Meja Kerja Menurunkan Beban Kerja Karyawan Kerajinan Logam di Kabupaten Tabanan Bali, Prosiding Seminar Nasional dan Kongres Ergonomi III, Teknik Industri, Universitas Trisakti, Jakarta

Andewi, P.J, 1999, Perbaikan Sikap Kerja dengan Memakai Kursi dan Meja Kerja yang Sesuai dengan Data Antropometri Pekerja dapat Meningkatkan Produktivitas Kerja dan Mengurangi Gangguan sistem Musculoskeletal, Thesis Magister, Pascasarjana Universitas Udayana, Denpasar, Bali.
Freivalds, A., 2010, Introduction to Work Design, http://www.learningace.com/ ,diakses pada 27 September 2015.

Ferdiansyah, H., 2009, Usulan Rencana Perbaikan Kualitas Produk Penyangga Duduk Jok Sepeda Motor dengan Pendekatan Kaizen (5WIH) di PT. Ekaprasarana, http://www.gunadarma.ac.id/, diakses pada 10 Agustus 2015.

Gadieswati, G., 2010, Usulan Penerapan konsep ergonomi makro dengan metode Macroergonomic Analysis and Design (MEAD) pada Pelayanan Obat Pasien Rawat Inap RSUP Dr. Hasan Sadikin Bandung, Laporan Tugas Sarjana, Program Studi Teknik Industri, ITB, Bandung.

Hendrick, H.W. and Kleiner, B.M., 2001, Macroergonomics : An Introduction To Work System Design, HFES Publisher, Santa Monica - USA.

Hendrick, H. W. and Kleiner, B.M., 2002, Macroergonomic: Theory, Method, and Application, https:// books.google.co.id, diakses 28 Maret 2016.

Iridiastadi, H. dan Yassierli, 2014, Ergonomi Suatu Pengantar, Cetakan Pertama, PT. Remaja Rosdakarya, Bandung.

Manuaba, A, 1998a, Bunga rampai Ergonomi, Vol. II, Program studi Ergonomi dan Fisiologi Kerja, Universitas Udayana, Denpasar.

Manuaba, A, 1998b, Task Demands, Working Capacity and Performance - A Holistic System Approach in Manual Material Handling, Proceeding Ergonomic Congres, November $18^{\text {th }} 1998$, Universitas Udayana, Denpasar.

Manuaba, A, 1999, Ergonomi Meningkatkan Kinerja Tenaga Kerja Perusahaan, Prosiding Simposium dan Pameran Ergonomi Indonesia, Bandung.

Manuaba, A, 2001, Integrated Ergonomics Approach Toward Designing Night and Shift Work in Developing Countries Based on Experienes in Bali, Indonesia, Jurnal Human Ergologi, Dec, 30(1-2).

Purnomo, H, A. Manuaba, dan N. Adiputra, 2007, Sistem Kerja dengan Pendekatan Ergonomi Total Mengurangi Keluhan Musculoskeletal, Kelelahan, dan beban Kerja serta Meningkatkan Produktivitas Pekerja Gerabah di Kasongan Bantul, E- 
Journal, www.purnomohari.or.id, diakses 22 November 2007

Sutajaya, 1999, Perbaikan proses kerja melalui perbaikan posisi kerja dengan perancangan alat bantu untuk pematung di Peliatan, Ubud, Gianyar Bali dapat mengurangi beban kerja dan gangguan musculoskeletal, Prosiding Simposium dan Pameran Ergonomi Indonesia, Bandung, Indonesia

Sutalaksana,I.Z., Anggawisastra,R., dan Tjakraatmadja,J.H., 1997, Teknik Tata Cara Kerja, Jurusan Teknik Industri ITB, Bandung.

Tarwaka, Bakri, S. H. A., dan Sudiajeng, L., 2004, Ergonomi: Untuk Keselamatan, Kesehatan Kerja, dan Produktivitas, UNIBA Press, Surakarta.

Wibawa, T, 2009, Perancangan Stasiun Kerja pada Industri Emping Melinjo dengan Pendekatan Human Centered Design (HCD), Jurnal OPSI, Teknik Industri, UPN "Veteran" Yogyakarta. 